\title{
Using vessel monitoring system (VMS) data to assess the impact of marine protection boundaries on blue ling fishing northwest of the British Isles
}

\author{
Paulette E. Posen ${ }^{\mathrm{a}}$, Janette LeE, Philip A. LARge and Andrew J. KenNY \\ Centre for Environment, Fisheries and Aquaculture Science, Pakefield Road, Lowestoft, Suffolk, NR33 0HT, UK
}

Received 12 February 2013; Accepted 4 June 2014

\begin{abstract}
In 2009, the European Commission set restricted fishing areas northwest of the British Isles to protect deep-sea vulnerable marine ecosystems and fish stocks. Two protection areas which, historically, have been targeted by fisheries directed at blue ling (Molva dypterygia), were defined. The study aims to assess the effectiveness of restricting fishing activity within the protection areas during the blue ling spawning period (March-May) and to determine whether the existing boundaries are fit for purpose. Estimations of the spatial apportionment of blue ling landings within and outside the protection areas are achieved by combining low-resolution data from fishing vessel logbook entries with higher-resolution vessel monitoring system (VMS) data. High-resolution spatial apportionment of blue ling landings is limited by a lack of high-resolution logbook data, and certain assumptions need to be made on whether vessels are engaging in fishing activity at any individual VMS data point, based on vessel speed and types of fishing gear available. Although current measures appear to have influenced fishing activity in the vicinity of the protection areas, more evidence is needed for a robust evaluation of their effectiveness in protecting blue ling. Recommendations are made for improvements in data collection methods and data availability for research in support of monitoring, assessment and delineation of marine protection boundaries.
\end{abstract}

Keywords: Blue ling / VMS / Trawl fisheries / Marine protected areas / Continental slope / Spatial management / Deep sea

\section{Introduction}

The protection of marine ecosystems and the sustainable use of European marine resources are the objectives of the Marine Strategy Framework Directive (MSFD) of the European Union (EC 2008), which sets measures for achieving good environmental status (GES) in Europe's seas by 2020. The Directive outlines 11 descriptors determining GES, encompassing all aspects of the marine environment and associated anthropogenic pressures. One of these descriptors requires populations of all commercially-exploited fish and shellfish to be exploited at levels not exceeding the maximum sustainable yield (MSY). The MSY objective is already integrated into the management of European fisheries, and the ongoing revision of the Common Fisheries Policy (EC 2002a) integrates the ecosystem approach from the MSFD where a healthy marine ecosystem is a prerequisite to achieve sustainable fisheries. This is an important departure from previous "sectoral" thinking. The new policy demands a more holistic and interdisciplinary approach to research, monitoring and assessment to achieve the ecosystem based management (EBM) objectives enshrined in

\footnotetext{
${ }^{a}$ Corresponding author: paulette.posen@cefas.co.uk
}

the MSFD. Within this context, the International Council for the Exploration of the Sea (ICES) regularly issues advice on matters including the management of the exploitation of living marine resources. This advice is based on a number of international agreements and policies promoting MSY or precautionary approaches to managing fisheries (UN 1982, 1992, 1995). A reaffirmation of the MSY approach, which uses scientific information to set catch allowances designed to maintain or restore species to sustainable levels, called for an urgent introduction of measures to restore depleted stocks, where possible, by 2015 (UN 2002). In support of these targets, ICES issues advice based on a framework that integrates precautionary, MSY and ecosystem approaches to fisheries management (ICES 2012a). Against this regulatory background, there has been a rapid increase in the development of restricted fishing areas to protect deep sea vulnerable marine ecosystems (VME) and/or fish stocks in recent years (EC 2002b). This study focuses on two such areas northwest of the British Isles where, in 2009, the European Commission (EC) introduced protection areas for spawning aggregations of blue ling (Molva dypterygia) in EU waters.

Blue ling is a deep water, bottom-dwelling, gadoid species, widely distributed in the north Atlantic from Newfoundland 


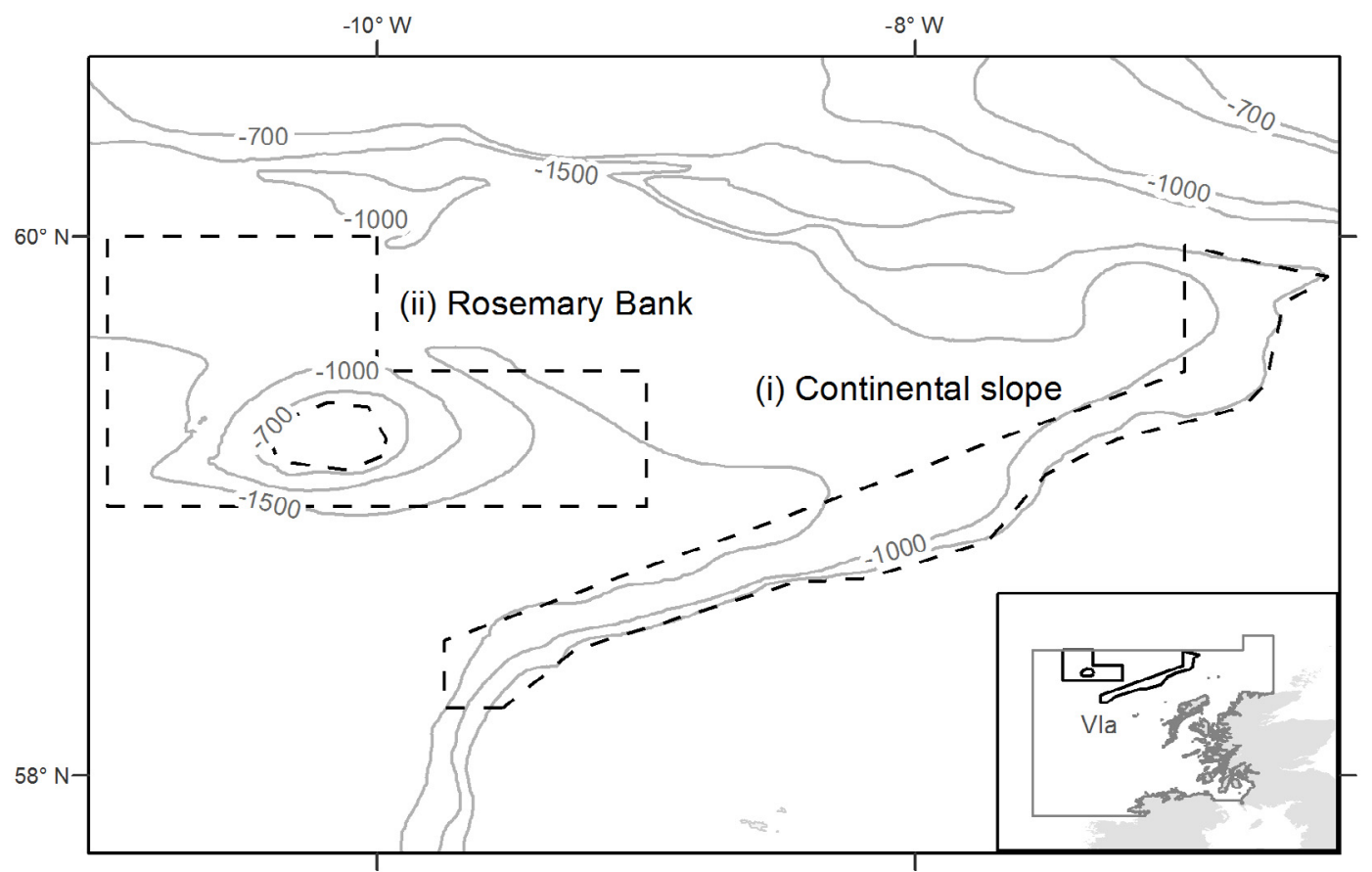

Fig. 1. Location of the Rosemary Bank and continental slope protection areas for spawning blue ling (dashed boundaries). The inset map shows the location of the protection area within ICES Division VIa.

and Greenland in the west, around the southern coast of Iceland, occasionally as far north as Spitsbergen, to the west of the British Isles and in the northern North Sea and Norwegian Sea. In the study area, the species is found between depths of 300 and $1500 \mathrm{~m}$, with peak abundance at 750-1000 m, mostly on muddy seabed (Cohen et al. 1990; Gordon and Hunter 1994; Large et al. 2010). Individuals are approximately $85 \mathrm{~cm}$ long at first maturity (males at 9 years, females at 11 years) growing to maximum reported length, weight and age of $155 \mathrm{~cm}$ (Cohen et al. 1990), $30 \mathrm{~kg}$ (Muus and Nielsen 1999) and 20 years (Cohen et al. 1990), respectively.

Historically, blue ling were targeted by commercial fisheries (especially in the northeast Atlantic) using bottom trawls and longlines but more recently, they have been taken mainly as bycatch in mixed trawl fisheries for roundnose grenadier and black scabbardfish (ICES 2012b). A rapid development of deepwater fisheries since the late 1980s overfished certain stocks, reaching unsustainable levels of fishing mortality for blue ling and roundnose grenadier northwest of the British Isles in the 1990s and early 2000s (ICES 2012b), although there is also evidence that catch rates may not reflect actual change in stock abundance (Harley et al. 2001).

A total allowable catch (TAC) of blue ling was introduced in 2003 (EC regulation 2340/2002). Further, ICES advised repeatedly (ICES 2004, 2006, 2008) on the susceptibility of blue ling to sequential depletion of spawning aggregations, resulting from high landings at spawning time until the 2000s. Based upon knowledge of the timing and location of spawning collated by Large et al. (2010), measures to protect spawning aggregations of blue ling in ICES Division VIa were introduced in EC regulation 43/2009 of 16 January 2009. Specifically, the regulation stipulates that, from 1 March to 31 May, there should be restrictions on fishing activity directed at blue ling within delimited areas of Division VIa (Fig. 1) along (i) the edge of the Scottish continental shelf, and (ii) the edge of Rosemary Bank. Within these areas the restrictions prohibit the retention on board any vessel of more than $6 \mathrm{t}$ blue ling per fishing trip, at which quantity a vessel should cease fishing immediately, exit the area in which it has been fishing, not reenter either protection area until the catch has been landed and not return any quantity of blue ling to the sea.

The designation of marine boundaries within which fishing activity is to be limited, or prohibited, to protect fish stocks is supported by data on parameters such as seafloor topography, marine habitats, spawning times and fishing activity, the last obtained from vessel logbook information or through onboard observation (Reed et al. 2005; Hall-Spencer et al. 2009; Ross et al. 2011; Armstrong et al. 2013). However, fish stock assessment is often hindered by an absence of supporting highresolution observation or monitoring data, requiring the application of various modelling techniques for analysis in support of regulatory and other purposes (Lorance et al. 2010; Trenkel et al. 2012; Augustin et al. 2013).

The spatial resolution of fishing effort estimation has been improved by incorporation of satellite-based vessel monitoring system (VMS) data into spatial analysis of fishing activity for conservation and management purposes (Davies et al. 2007; Fock 2008; Chang 2011). High-resolution estimates of fishing effort and landings can be derived by combining VMS data with vessel logbook entries to estimate spatial and temporal patterns of fishing activity at multiple scales (Mills et al. 2007; Bertrand et al. 2008; Bastardie et al. 2010; Lee et al. 2010; Gerritsen and Lordan 2011; Joo et al. 2011; Jennings and Lee 2012). These estimates, derived using a variety of techniques, are based on vessel speed, direction, and fishing gear available, but are limited by a lack of data regarding the actual activity 
at individual VMS locations. VMS signals record an accurate vessel position every $2 \mathrm{~h}$, reducing to a 30-min interval when vessels are within restricted fishing areas (EC Regulation 1224/2009), but do not record whether the vessel is actively fishing at that time and location. Landings data comprise logbook declarations provided by commercial fishermen which detail the landed weight per species per ICES rectangle of $0.5^{\circ}$ latitude $\times 1^{\circ}$ longitude, by day and gear type. A new logbook entry is recorded on change of date, gear or ICES rectangle. Logbook data are combined with sales information to provide weight and value of landings for each species. Nevertheless, assigning landings to VMS points collected at different temporal intervals relies on certain assumptions.

Here, an assessment of the impacts of restricting fishing activity within the two protection zones during the spawning season of blue ling was carried out. The work included detailed analyses of fishing activity for blue ling during the period 2007-2010 in order to: (i) estimate the apportionment of blue ling landed from inside and outside the EC protection areas during the blue ling spawning period (March-May); (ii) assess the effectiveness of fishing restrictions by estimating changes in the spatial distribution of blue ling landings and inferred fishing activity during the spawning periods of 2007-2010 (straddling the 2009 implementation of measures) to evaluate whether the current protection boundaries are fit for purpose.

\section{Methods}

A summary analysis of blue ling landings in relation to total fishing activity was performed for the 2002-2013 period, including a more focused analysis of blue ling fishing activity during the March-May closure period for the years 2007-2010, to investigate changes in magnitude and spatial pattern of landings in the years before and after introduction of the protection areas.

\subsection{Processing of VMS data}

High-resolution fishing activity was estimated by combining VMS data for all vessels $\geq 15 \mathrm{~m}$ length overall landing into the UK from ICES Division VIa with landings data from a subset of ICES rectangles encompassing the continental slope and Rosemary Bank protection areas (Fig. 1). The methods used to estimate fishing activity are described in Lee et al. (2010) and Jennings and Lee (2012). In summary, after preliminary screening to remove inaccuracies and duplicates, VMS data were linked to vessel logbook information based on vessel identifier, date and time, and location (ICES rectangle) to determine the fishing gear being employed. Data were subset and points with a reported vessel speed of between 1 and 6 knots were flagged as indicating fishing activity for trawlers (which land about $99 \%$ of the UK's take of blue ling). The time interval between successive VMS locations was summed to provide an estimate of fishing effort. Landings data were apportioned (by vessel, date, time and location) to the flagged data points in direct proportion to the estimated fishing effort, thereby ensuring that the landings allocation would not be adversely affected by the differing VMS reporting frequencies inside/outside of the protection areas. Processing and mapping of data were performed using ESRI ArcGIS v9.3 (http://www.esri.com/) and the R statistical software (http://www.r-project.org/).

\subsection{Estimation of blue ling fishing activity in relation to protection areas}

The determination of landings values within, or outside, the protection areas was achieved by simply summing the allocated landings from the VMS points according to whether or not the point fell within the protection area boundaries.

\subsection{Assumptions in landings estimation during the spawning period for blue ling}

The estimations relied on the assumptions outlined below.

(i) Landings allocation to VMS points was based on a speed rule of 1-6 knots being representative of fishing activity (by trawlers in particular) following a detailed review of published methods to estimate the spatial distribution of fishing from VMS (Lee et al. 2010). Note that the results of other studies have suggested that trawlers fish within different speed ranges (e.g. 1.5-4.5 knots, Hall-Spencer et al. 2009; 2-8 knots, Mills et al. 2007). Any fishing activity occurring outside of the 1-6 knot speed range will therefore not have been identified (thus excluded from the analysis) and any non-fishing activity within this speed range will have been misclassified as fishing activity.

(ii) Landings allocations to VMS points indicating "fishing" were proportional to ping intervals between consecutive VMS locations for individual vessels and for each reported episode of fishing activity. This approach assumes that trawling activity and landings are directly related at any scale smaller than one ICES rectangle.

(iii) Peak spawning season for blue ling is March to May within ICES Division VIa (Large et al. 2010). This assumption was based on limited biological evidence from the literature.

Given these assumptions it is possible that some fishing activity may be occurring, and being reported in the landings data, at locations which have not been identified by the speed-based filtering of the VMS analysis. Conversely, some fishing activity may be identified from the VMS data to which (based on vessel identifier, location and date) no landings information can be attributed.

\section{Results}

\subsection{Summary analysis}

Plots of estimated monthly landings of blue ling from protection areas (Fig. 2) and a summary of blue ling landed during the spawning season (Table 1) indicate substantial reductions in landings during the 2009-2013 spawning seasons (MarchMay), compared with the same period for the preceding seven 

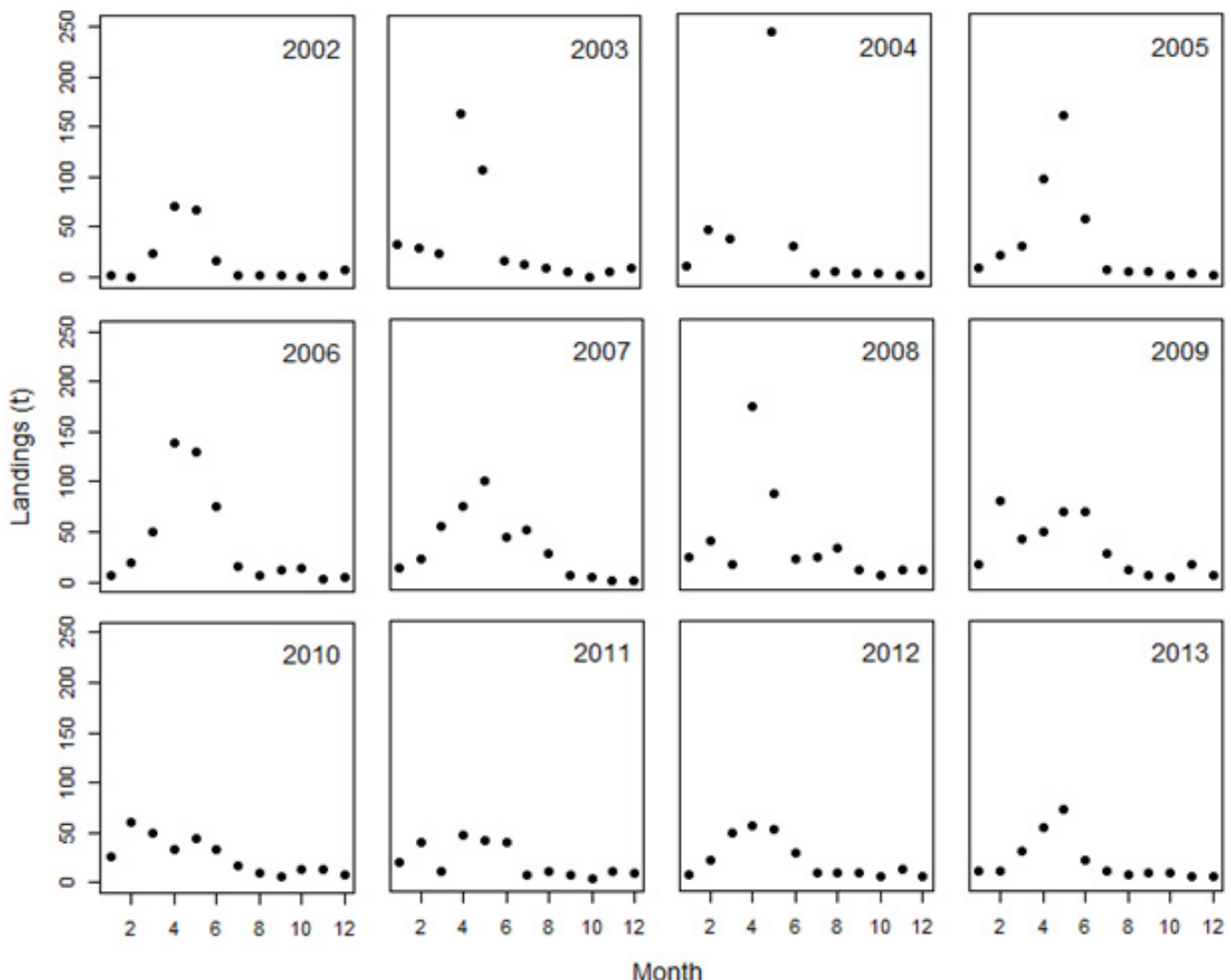

Fig. 2. Plots of monthly blue ling landings from the Rosemary Bank and continental slope protection areas, estimated from summation of VMS-apportioned data.

Table 1. Blue ling landings, number of vessels having caught any quantity of blue ling and total fishing effort of these vessels within the protection areas, and within the whole of ICES Division VIa, during the spawning season (March-May).

\begin{tabular}{ccccccc}
\hline $\begin{array}{c}\text { Fishing } \\
\text { activity }\end{array}$ & \multicolumn{3}{c}{ Within protection areas } & \multicolumn{2}{c}{ Within ICES Division VIa } \\
\hline Year & $\begin{array}{c}\text { Blue ling } \\
\text { landings } \\
\text { (t) }\end{array}$ & $\begin{array}{c}\text { No. of } \\
\text { vessels }\end{array}$ & $\begin{array}{c}\text { Estimated } \\
\text { fishing effort } \\
\text { (h) }\end{array}$ & $\begin{array}{c}\text { Blue ling } \\
\text { landings } \\
\text { (t) }\end{array}$ & $\begin{array}{c}\text { No. of } \\
\text { vessels }\end{array}$ & $\begin{array}{c}\text { Estimated } \\
\text { fishing effort } \\
\text { (h) }\end{array}$ \\
\hline 2002 & 161 & 13 & 2070 & 617 & 28 & 7117 \\
2003 & 296 & 21 & 1616 & 580 & 30 & 4397 \\
2004 & 560 & 19 & 1060 & 942 & 25 & 2386 \\
2005 & 284 & 19 & 1237 & 457 & 22 & 2983 \\
2006 & 321 & 24 & 2995 & 817 & 31 & 10020 \\
2007 & 228 & 16 & 2147 & 568 & 22 & 6154 \\
2008 & 276 & 14 & 2151 & 602 & 24 & 6850 \\
2009 & 158 & 17 & 1901 & 561 & 25 & 9331 \\
2010 & 126 & 18 & 1610 & 434 & 23 & 6944 \\
2011 & 95 & 13 & 1007 & 410 & 16 & 5798 \\
2012 & 154 & 11 & 966 & 465 & 14 & 4562 \\
2013 & 153 & 8 & 744 & 443 & 11 & 3825 \\
\hline
\end{tabular}

years. Mean annual blue ling landings from the protection areas for the 2002-2008 spawning seasons were $304 \mathrm{t}$, so a mean value of $137 \mathrm{t}$ for 2009-2013 (Table 1) represents a 55\% reduction from the mean 2002-2008 landings value. These landings should also be considered in the context of numbers of vessels fishing for, and landing, blue ling during the spawning season. In 2002 there were 13 vessels landing blue ling from within the protection area (the lowest number recorded during 2002-2008, pre-implementation of measures) and fishing for an estimated $2000 \mathrm{~h}$ during this three month period; the highest pre-implementation values, recorded for 2006, indicate 24 vessels fishing for an estimated $3000 \mathrm{~h}$. However, although there was no reduction in the number of vessels fishing inside the protection area in 2009 and 2010 compared with the average of 18 vessels over the previous years examined (Table 1), there appears to have been a steady decline in vessel numbers 
Table 2. Breakdown of number of vessels by proportion of blue ling in the total landings for vessels fishing within the protection areas during the spawning season (March-May).

\begin{tabular}{|c|c|c|c|c|c|}
\hline \multirow[t]{2}{*}{ Year } & \multicolumn{4}{|c|}{$\begin{array}{l}\text { No. of vessels vs. percentage of landings } \\
\text { from blue ling }\end{array}$} & \multirow{2}{*}{$\begin{array}{l}\text { Total no. } \\
\text { of vessels }\end{array}$} \\
\hline & $<25 \%$ & $25-50 \%$ & $50-75 \%$ & $>75 \%$ & \\
\hline 2002 & 3 & 8 & 2 & 0 & 13 \\
\hline 2003 & 8 & 9 & 2 & 2 & 21 \\
\hline 2004 & 3 & 6 & 9 & 1 & 19 \\
\hline 2005 & 1 & 8 & 8 & 2 & 19 \\
\hline 2006 & 5 & 12 & 6 & 1 & 24 \\
\hline 2007 & 7 & 7 & 2 & 0 & 16 \\
\hline 2008 & 6 & 5 & 3 & 0 & 14 \\
\hline 2009 & 7 & 8 & 2 & 0 & 17 \\
\hline 2010 & 10 & 6 & 2 & 0 & 18 \\
\hline 2011 & 5 & 7 & 1 & 0 & 13 \\
\hline 2012 & 6 & 4 & 1 & 0 & 11 \\
\hline 2013 & 2 & 4 & 2 & 0 & 8 \\
\hline
\end{tabular}

Table 3. Comparison between aggregated blue ling landings per unit effort $\left(\mathrm{t} \mathrm{h}^{-1}\right)$ within the protection areas, and in the rest of ICES Division VIa, during the spawning season (March-May).

\begin{tabular}{ccc}
\hline & \multicolumn{2}{c}{$\begin{array}{c}\text { Estimated blue ling landings per } \\
\text { unit effort }\end{array}$} \\
\cline { 2 - 3 } Year & $\begin{array}{c}\text { Inside } \\
\text { protection areas }\end{array}$ & $\begin{array}{c}\text { ICES Division } \\
\text { VIa, outside } \\
\text { protection areas }\end{array}$ \\
\hline 2002 & 0.078 & 0.090 \\
2003 & 0.183 & 0.102 \\
2004 & 0.528 & 0.288 \\
2005 & 0.230 & 0.099 \\
2006 & 0.107 & 0.071 \\
2007 & 0.106 & 0.085 \\
2008 & 0.128 & 0.069 \\
2009 & 0.083 & 0.054 \\
2010 & 0.078 & 0.058 \\
2011 & 0.094 & 0.066 \\
2012 & 0.159 & 0.086 \\
2013 & 0.206 & 0.094 \\
\hline
\end{tabular}

during subsequent years, to a mere 8 vessels in 2013. These figures reflect vessels reporting any blue ling within their landings. In order to better investigate the vessels actively targeting blue ling the data were summarised to indicate vessels where blue ling comprised a large proportion of the total landings. The contribution from blue ling to the reported landings for vessels fishing inside the protection area during the spawning season is given in Table 2. The figures show that in recent years most vessels fishing within the closed area report $<25 \%$ of their landed catch weight as blue ling. No vessels (since 2007) have reported blue ling as contributing $>75 \%$ of their landed catch and the number of vessels landing between 50 and $75 \%$ blue ling has also decreased. Meanwhile, Table 3 compares annual estimates of blue ling landings per unit effort from within and outside the protection areas of ICES Division VIa, and indicates that, with the exception of 2002, landings per unit effort during the closure period were consistently higher inside, than outside, the protection areas. Furthermore, although there was a substantial reduction in blue ling landings per unit effort during the three years after closure implementation, both inside and outside the protection areas, since 2011 there has been a steady increase to pre-implementation levels, particularly inside the protection areas. Based on all vessels reporting any blue ling landings during 2010, blue ling landings $>6 \mathrm{t}$ were recorded for $20 \%$ of a total 452 fishing trips. This corresponded to a total of 68 vessels (mean length $38 \mathrm{~m}$; maximum length $72 \mathrm{~m}$ ), of which 19 reported trips where blue ling landings exceeded $6 \mathrm{t}$. In general, for those vessels landing $>6 \mathrm{t}$ blue ling per trip, higher total landings corresponded to lower proportions of blue ling in the composition.

Between 2002 and 2008 blue ling landings from the protection areas generally peaked during April or May (Fig. 2) and substantial reductions in peak landings values were seen during the 2009-2013 closure periods, compared with the average peak landings for the preceding years. During the 2009 closure period, landings peaked in May, at $44 \%$ of the average peak levels for the preceding seven years. This was followed by further declines in peak landings during 2010 and 2011, to $32 \%$ and $29 \%$, respectively, of the 2002-2008 average. It should be noted from Figure 2 that blue ling landings from the protection areas peaked in February (prior to the start of the spawning season) during 2009 and 2010, at $78 \mathrm{t}$ and $60 \mathrm{t}$, respectively, compared with landings of $21 \mathrm{t}$ in February 2007 and $40 \mathrm{t}$ in February 2008. These findings could have indicated the onset of a drive to maximise landings before implementation of the first seasonal closure at the beginning of March 2009, and immediately prior to the seasonal closure in 2010; however, this was not observed in subsequent years.

The spatial distribution of blue ling landings at the scale of the ICES rectangle, as a proportion of total landings (all species) during the spawning periods 2007-2010, is presented in Figure 3. This period covers the transition between pre- and post-closure implementation in January 2009. All maps show (i) total landings weight (all species) during the closure period (graduated pie charts representing total weight recorded per rectangle); and (ii) blue ling landings as a proportion of total landings (all species) during the closure period (black portion of graduated pie chart). Most nobably, the charts suggest that in 2010 a reduction in blue ling landings from the vicinity of the continental slope protection area may have been offset by an increase in landings of other species.

\subsection{Summing VMS-apportioned blue ling landings inside and outside the protection areas}

The results of blue ling landings apportioned to VMS points within and outside the protection area boundaries are summarised in Table 4. These results indicate that there may have been a small shift in apportionment of blue ling landings away from the continental slope protection area, and a more substantial shift away from Rosemary Bank, during the closure period post-implementation of measures. However, the results need to be viewed with caution, since many of the VMS points along the continental slope straddle the boundary of the protection area (Fig. 4), introducing a great deal of uncertainty into the apportionment of landings values either side of this boundary. Therefore, it is unrealistic to state confidently that there has been any real reduction in landings from within 

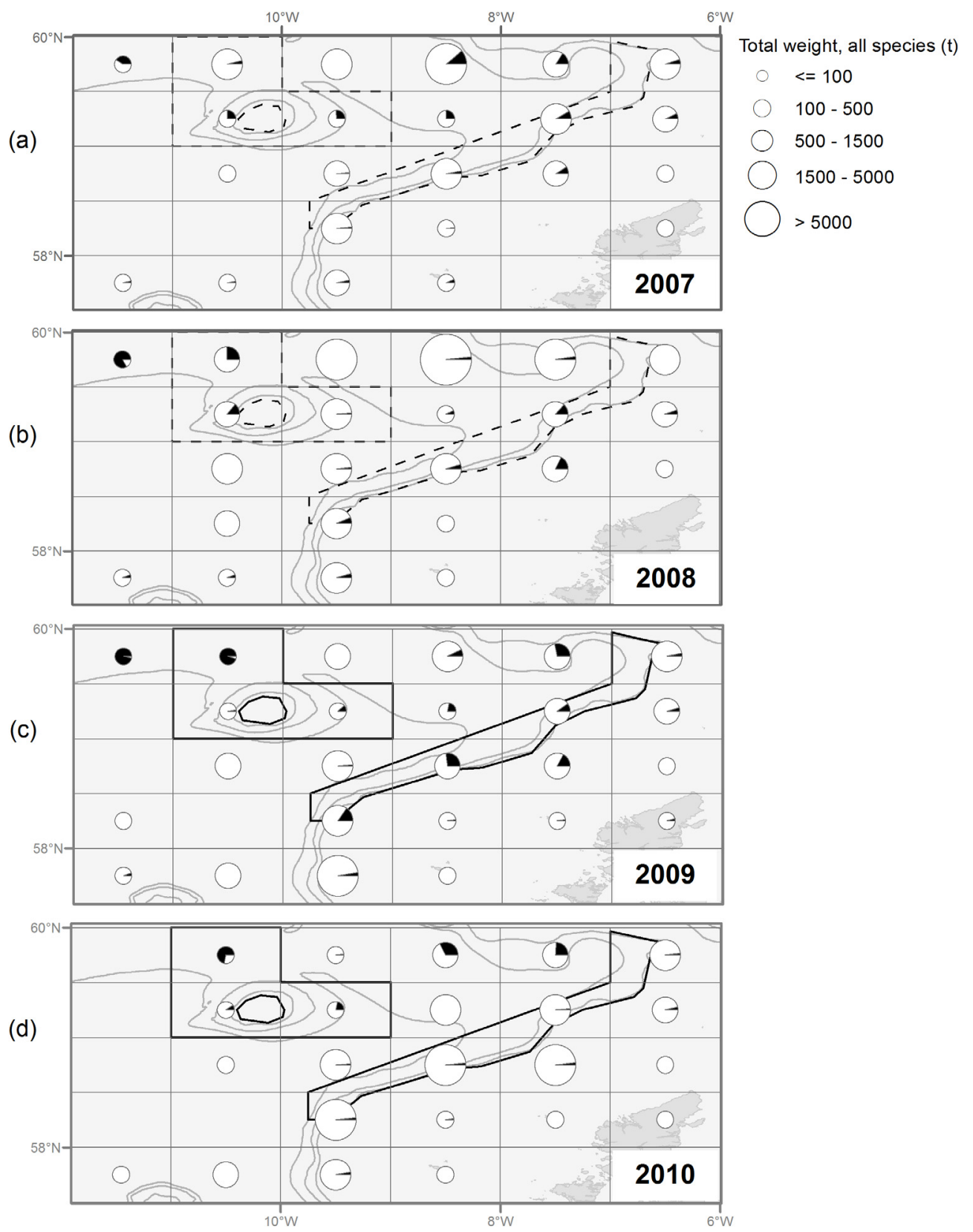

Fig. 3. Spatial distribution of landings at ICES rectangle level during March-May (i.e. the closure period implemented from 2009 ): (a) 2007 and (b) 2008 (pre-implementation); (c) 2009 and (d) 2010 (post-implementation). Logbook landings data are shown by a scaled pie chart at the centre of each rectangle (pie size symbolises total landings weight, all species); black segment represents blue ling proportion of total. Depth contours shown are 700, 1000 and $1500 \mathrm{~m}$.

the protection areas arising from implementation of the annual closures.

\subsection{Interannual variations in the spatial distribution of blue ling fishing intensity}

Annual variations in the spatial distribution of fishing intensity during the spawning period, for VMS-apportioned data where blue ling represents $>75 \%$ of total landings, are evident in Figure 4 . There are between-year variations in locations associated with the most intense activity, but the data reveal the greatest concentration of fishing activity along the continental slope. There appears to have been some southward displacement of the most intense fishing activity to just outside the continental slope protection boundary after closure implementation.

\section{Discussion}

The analysis indicates that there has been a decrease in both effort directed toward, and landings of, blue ling within the protection areas. There has been a corresponding decrease 
Table 4. Percentage estimates of blue ling landed annually (20022013) during the period March-May, derived from VMS-apportioned landings data (using the method of Lee et al. 2010) summed within protected areas, and in non-protected areas, of ICES Division VIa.

\begin{tabular}{cccc}
\hline \multirow{2}{*}{ Year } & $\begin{array}{c}\text { Estimated \% } \\
\text { blue ling from non- } \\
\text { protected areas of }\end{array}$ & \multicolumn{2}{c}{$\begin{array}{c}\text { Estimated \% blue ling from } \\
\text { inside protection areas }\end{array}$} \\
\cline { 3 - 4 } & ICES Division VIa & $\begin{array}{c}\text { Continental } \\
\text { slope }\end{array}$ & $\begin{array}{c}\text { Rosemary } \\
\text { Bank }\end{array}$ \\
\hline 2002 & 74 & 26 & 0 \\
2003 & 49 & 41 & 10 \\
2004 & 40 & 55 & 5 \\
2005 & 38 & 54 & 8 \\
2006 & 61 & 26 & 13 \\
2007 & 60 & 29 & 11 \\
2008 & 56 & 27 & 17 \\
2009 & 72 & 26 & 2 \\
2010 & 71 & 23 & 6 \\
2011 & 77 & 23 & 0 \\
2012 & 67 & 26 & 7 \\
2013 & 65 & 33 & 1 \\
\hline
\end{tabular}

in the number of vessels reporting blue ling landings from within the protection areas during the annual closure period, but the steady increase in estimated landings per unit effort since 2011 suggests that those vessels landing blue ling may be fishing more efficiently. The catch composition also seems to have changed since the measures to protect the spawning aggregations have been in place, with fewer vessels recording $>50 \%$ blue ling, and more vessels recording $<25 \%$ blue ling, in their haul, compared with the period 2002-2008. This observation could reflect either a scarcity of blue ling due to stock depletion, or that fishermen are actively respecting the closure and fishing for other species. There is little support for the first hypothesis as blue ling abundance, at stock level, is estimated to have increased by a factor of 2 or 3 over the period 2004-2010 (ICES 2012b; Trenkel et al. 2012), an increase which was apparent in both spawning and other areas (Augustin et al. 2013). Nevertheless, the results should be interpreted cautiously, given the assumptions made and uncertainties involved. The annual plots (2002-2013; Fig. 2) suggest that there has been an overall reduction in total landings of blue ling during the spawning seasons since implementation of the closures in 2009, although a small but steady rise in peak landings during the closure periods has been evident since 2012.

The accuracy of spatial apportionment of blue ling landings in relation to the protection areas is limited by data availability and consequent assumptions that need to be made in its estimation. The scale of the ICES rectangle (at which landings data are currently available) is coarse in relation to the spatial distribution of VMS data points (Fig. 4), so the apportionment of landings values to VMS point locations may not give a reliable indication of where fishing activity is in relation to the boundaries of protection areas, especially for VMS signals close to those boundaries. Several studies have analysed the uncertainties in assessing vessel trajectories between successive VMS points and the validation of VMSderived fishing effort (Fock 2008; Palmer 2008; Walker and Bez 2010; Gerritsen and Lordan 2011; Russo et al. 2011).
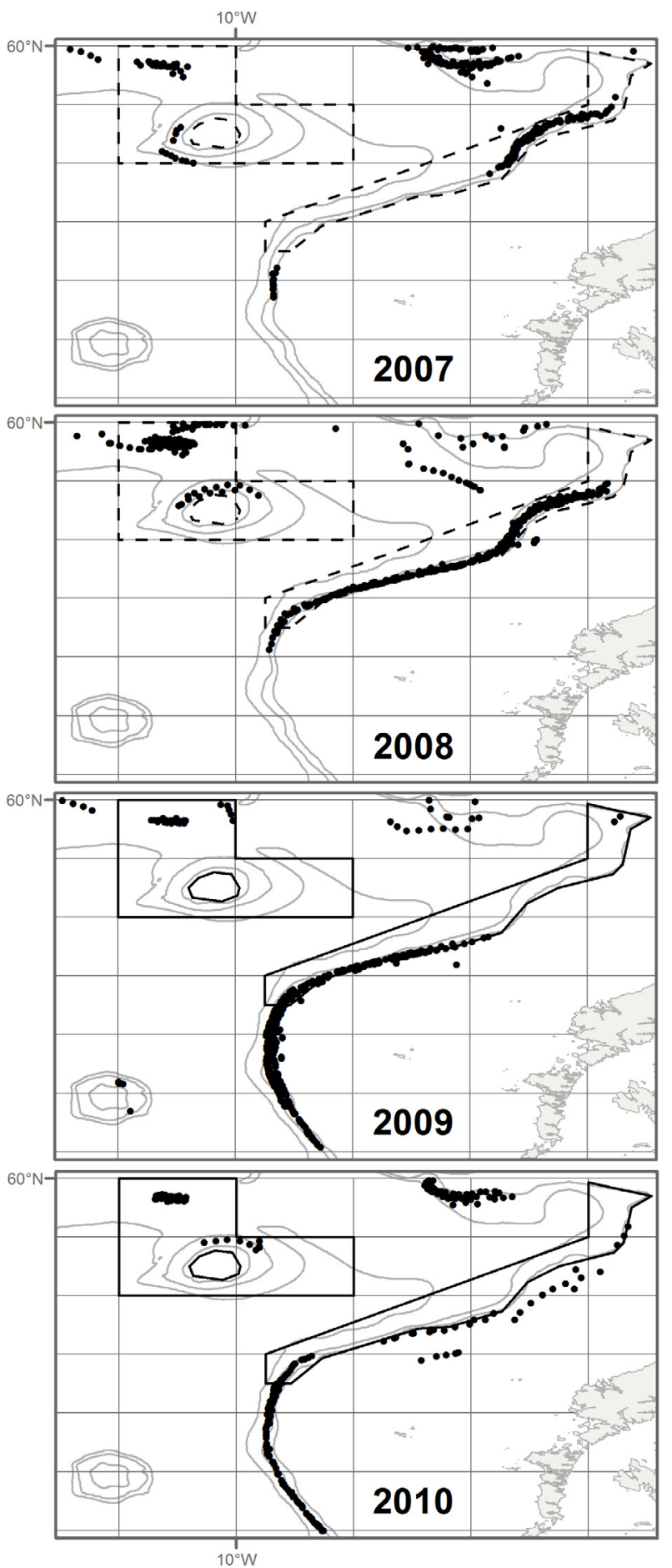

Fig. 4. Spatial distribution of VMS fishing locations where allocated blue ling landings represented $>75 \%$ of total landings, during March to May for the period 2007 to 2010. The locations of the Rosemary Bank and continental slope protection areas are indicated by dashed boundaries (before closure implementation) and solid boundaries (after closure implementation). Depth contours shown are 700, 1000 and $1500 \mathrm{~m}$.

Tools have been developed specifically to assist in the identification and analysis of fishing activity from VMS and logbook data (Hintzen et al. 2010; Hintzen et al. 2012) and, in 
the wider context of identifying and analysing movement patterns from large and complex datasets, Enguehard et al. (2013) have performed a comparative study of different approaches to the exploration of spatiotemporal fisheries movement data from VMS.

There is little evidence to suggest that non-spatial policy drivers such as TAC would, necessarily, affect the spatial distribution of blue ling landings in the manner seen in this study. Interannual variability in the spatial distribution of the landings (inferred from VMS signals) suggests that additional factors may have been influencing fishing activity. For instance, previous research has indicated that changes in sea temperature, currents, subsurface upwelling and attendant food availability (associated not only with seasonal and interannual variability, but also with less predictable events such as storms and turbidity currents) can influence the migratory routes of deep sea fish and their choice of location for gonad development and spawning activity (Overholtz et al. 2011; Crawford et al. 2012; Jury 2012; Olafsdottir and Rose 2012). The variability is often reflected in the spatial distribution of fishing activity, as captured in Figure 4; in general, annual fluctuations in the regions of greatest intensity tend to travel back and forth along the depth contours of the continental slope. There appears to have been a shift from general dispersion of fishing activity along the continental slope in 2008 to more localised activity in the area immediately south-southwest of the continental slope protection area boundary during 2009 and 2010. It also appears that in 2009 and 2010, post-implementation of the protection areas, there was a southwestward shift of fishing intensity along the continental slope protection area to just beyond the most southerly extent of its boundary. This suggests that there had been some displacement of fishing activity for blue ling arising from implementation of the closures. However, the shift of focused activity towards that location may indicate that the area immediately beyond the continental slope closure boundary is also important for spawning aggregations. In general, fishers are known to return habitually to locations where they have fished successfully in the past (Hiddink et al. 2006; Stelzenmuller et al. 2008) and this has been observed also for deep-water fishing fleets (Marchal et al. 2013).

Furthermore, the displacement of the blue ling fishery to areas previously not heavily fished could be detrimental to potential vulnerable marine ecosystems (VMEs) which are known and predicted to occur in this region, e.g. VMEs dominated by a Foraminifera xenophyophore Syringammina fragilissima and the deep water coral Lophelia pertusa (Ross and Howell 2013). Indeed, Hiddink et al. (2006) argued that strongest potential negative effect of fisheries displacement is typically associated with closing areas which are heavily fished, thus forcing fleets to move to lesser fished areas. In habitats that have low natural resilience, such as in the deep sea, this may generate a higher impact on the benthic ecosystem. The fact that the blue ling closures are seasonal (for 3 months between March and May) is unlikely to lessen the potential impact on the benthic marine ecosystem or the blue ling stocks, as evidenced by the relatively small reductions in landings data from the present study.

These findings, combined with the uncertainty surrounding quantifying activity close to the protection area boundaries, underscore the need for close monitoring and robust analysis to support the delineation, and possible revision, of boundary limits. This could be achieved by haul-by-haul reporting of catch in logbooks, which would allow the matching of VMSidentified fishing activity, (i.e. hauls at a given time and location) to the catch reported for one single haul. This haul-byhaul reporting would not necessarily require accurate location to be recorded, as successive hauls during one day could be associated to successive fishing locations inferred from VMS, provided the VMS frequency is sufficient to properly identify hauls. The latter implies increasing the VMS signalling frequency outside protection areas, where the current $2 \mathrm{~h}$ frequency requires several assumptions to allocate landings to VMS points. Nevertheless, the results of this study may go some way to aid the redefinition of these boundary limits, such as to the south of the current closure on the continental slope.

Without having detailed logbook information from all vessels operating in the fishery, it is difficult to draw firm conclusions regarding the impact and current effectiveness of measures to protect the spawning aggregations of blue ling along the Scottish continental slope and on Rosemary Bank. Both the low spatial resolution of logbook data and the low VMS frequency outside of the spawning areas have some bearing on this difficulty. Changes to other regulations (such as decreasing TACs) and in fish abundance (i.e. increasing stock biomass over the study period) further complicate the interpretation of the results of this study. Of course, a major hindrance to evaluating the effectiveness of the protection areas is that catching blue ling in these areas during the spawning season is restricted, but not banned. It is likely that displaced fishing activity still targets spawning aggregations, but there is insufficient biological evidence to support that hypothesis. However, the results lend support to the continued precautionary approach to the management of the blue ling fishery as recommended by ICES (2012b), e.g. that "area closures to protect spawning aggregations [of blue ling] should be maintained and expanded as appropriate". Furthermore, it is possible that spawning aggregation sites are widespread along the continental slope and, without detailed knowledge of where these aggregations take place, a more spatially extensive closure along the continental slope would be needed to ensure blue ling protection during the spawning season. This, of course, would have a large negative impact on wider fisheries where blue ling is taken as bycatch, highlighting the problem of protecting a stock that forms part of a mixed fishery. More biological data would facilitate better delineation of the spawning areas of blue ling and support any necessary revision of the current protection area boundaries, while limiting adverse impacts on mixed fisheries.

Further work is being carried out to evaluate different methods for high-resolution spatial apportionment of landings data and, although testing of the sensitivity of the landings apportionment to vessel speed/fishing activity assumptions was outside the scope of the study, we believe that doing so would add a further test of the robustness of the estimation method. In our opinion, there would be merit in:

a) recording logbook catch and effort data on a haul-by-haul basis to facilitate evaluation of marine closures. This would probably also facilitate several other studies without being 
a big burden to vessels and skippers, as mostly 3-5 hauls per day are made in the studied fisheries;

b) increasing the VMS signalling frequency in all areas (not just marine protection areas) to improve the estimation of high-resolution fishing activity;

c) installing automatic on-board sensors on fishing gears to assist with assessment and monitoring actual fishing activity, rather than relying on assumptions based on gear type and speed rules, etc.

Acknowledgements. This study was carried out at the Centre for Environment, Fisheries and Aquaculture Science (Cefas), UK, with financial support from the Commission of the European Communities under the DEEPFISHMAN project (Grant agreement No. 227390). The reviewers of this article are thanked for their insightful comments, which have complemented and enhanced the original manuscript.

\section{References}

Armstrong M.P., Dean M.J., Hoffman W.S., Zemeckis D.R., Nies T.A., Pierce D.E., Diodati P.J., McKiernan D.J., 2013, The application of small scale fishery closures to protect Atlantic cod spawning aggregations in the inshore Gulf of Maine. Fish. Res. $141,62-69$.

Augustin N.H., Trenkel V.M., Wood S.N., Lorance P., 2013, Spacetime modelling of blue ling for fisheries stock management. Environmetrics 24, 109-119.

Bastardie F., Nielsen J.R., Ulrich C., Egekvist J., Degel H., 2010, Detailed mapping of fishing effort and landings by coupling fishing logbooks with satellite-recorded vessel geo-location. Fish. Res. 106, 41-53.

Bertrand S., Díaz E., Lengaigne M., 2008, Patterns in the spatial distribution of Peruvian anchovy (Engraulis ringens) revealed by spatially explicit fishing data. Prog. Oceanogr. 79, 379-389.

Chang S.-K., 2011, Application of a vessel monitoring system to advance sustainable fisheries management - Benefits received in Taiwan. Mar. Policy 35, 116-121.

Cohen D.M., Inada T., Iwamoto T., Scialabba N., 1990, Gadiform fishes of the world (Gadiformes). An annotated and illustrated catalogue of cods, hakes, grenadiers and other gadiform fishes known to date. FAO Fisheries Synopsis 125(10). Rome, FAO, $442 \mathrm{p}$.

Crawford R., Vagle S., Carmack E., 2012, Water mass and bathymetric characteristics of polar cod habitat along the continental shelf and slope of the Beaufort and Chukchi seas. Polar Biol. 35, 179-190.

Davies A.J., Roberts J.M., Hall-Spencer J., 2007, Preserving deep-sea natural heritage: Emerging issues in offshore conservation and management. Biol. Conserv. 138, 299-312.

EC, 2002a, Regulation No 2371/2002 of 20 December 2002 on the conservation and sustainable exploitation of fisheries resources under the Common Fisheries Policy. OJ L 358, 31.12.2002, 59-80.

EC, 2002b, Regulation No 2347/2002 of 16 December 2002 establishing specific access requirements and associated conditions applicable to fishing for deep-sea stocks. OJ L 351, 28.12.2002, 6-11.
EC, 2008, Directive 2008/56/EC of the European Parliament and of the Council of 17 June 2008 establishing a framework for community action in the field of marine environmental policy (Marine Strategy Framework Directive). OJ L 164, 25.6.2008, pp. 19-40.

Enguehard R.A., Devillers R., Hoeber O., 2013, Comparing interactive and automated mapping systems for supporting fisheries enforcement activities-a case study on vessel monitoring systems (VMS). J. Coast. Conserv. 17, 105-119.

Fock H.O., 2008, Fisheries in the context of marine spatial planning: Defining principal areas for fisheries in the German EEZ. Mar. Policy 32, 728-739.

Gerritsen H., Lordan C., 2011, Integrating vessel monitoring systems (VMS) data with daily catch data from logbooks to explore the spatial distribution of catch and effort at high resolution. ICES J. Mar. Sci. 68, 245-252.

Gordon J.D.M., Hunter J.E., 1994, Study of deep-water fish stocks to the west of Scotland. Unpublished Rep., Dunstaffnage Marine Laboratory, Oban, Scotland.

Hall-Spencer J.M., Tasker M., Soffker M., Christiansen S., Rogers S., Campbell M., Hoydal K., 2009, Design of Marine Protected Areas on high seas and territorial waters of Rockall Bank. Mar. Ecol. Prog. Ser. 397, 305-308.

Harley S.J., Myers R.A., Dunn A., 2001, Is catch-per-unit-effort proportional to abundance? Can. J. Fish. Aquat. Sci. 58, 1760-1772.

Hiddink J.G., Hutton T., Jennings S., Kaiser M.J., 2006, Predicting the effects of area closures and fishing effort restrictions on the production, biomass, and species richness of benthic invertebrate communities. ICES J. Mar. Sci. 63, 822-830.

Hintzen N.T., Piet G.J., Brunel T., 2010, Improved estimation of trawling tracks using cubic Hermite spline interpolation of position registration data. Fish. Res. 101, 108-115.

Hintzen N.T., Bastardie F., Beare D., Piet G.J., Ulrich C., Deporte N., Egekvist J., Degel H., 2012, VMStools: Open-source software for the processing, analysis and visualisation of fisheries logbook and VMS data. Fish. Res. 115, 31-43.

ICES, 2004, Report of the ICES Advisory Committee on Fishery Management and Advisory Committee on Ecosystems 2004, ICES Advice 1(2), $1544 \mathrm{p}$.

ICES, 2006, Report of the ICES Advisory Committee on Fishery Management, Advisory Committee on the Marine Environment and Advisory Committee on Ecosystems, 2006. Widely distributed and migratory stocks, ICES Advice 2006, Book 9, 255 p.

ICES, 2008, Report of the ICES Advisory Committee, 2008. Widely distributed and migratory stocks, ICES Advice 2008, Book 9.

ICES, 2012a, General context of ICES advice. ICES Advice 2012, Book 1.

ICES, 2012b, Report of the ICES Advisory Committee 2012, Book 9. Widely distributed and migratory stocks.

Jennings S., Lee J., 2012, Defining fishing grounds with vessel monitoring system data. ICES J. Mar. Sci. 69, 51-63.

Joo R., Bertrand S., Chaigneau A., Ñiquen M., 2011, Optimization of an artificial neural network for identifying fishing set positions from VMS data: An example from the Peruvian anchovy purse seine fishery. Ecol. Model. 222, 1048-1059.

Jury M.R., 2012, Physical oceanographic influences on Central Benguela fish catch. Earth Interactions 16, 1-15.

Large P.A., Diez G., Drewery J., Laurans M., Pilling G.M., Reid D.G., Reinert J., South A.B., Vinnichenko V.I., 2010, Spatial and temporal distribution of spawning aggregations of blue ling (Molva dypterygia) west and northwest of the British Isles. ICES J. Mar. Sci. 67, 49-501. 
Lee J., South A.B., Jennings S., 2010, Developing reliable, repeatable, and accessible methods to provide high-resolution estimates of fishing-effort distributions from vessel monitoring system (VMS) data. ICES J. Mar. Sci. 67, 1260-1271.

Lorance P., Pawlowski L., Trenkel V.M., 2010, Standardizing blue ling landings per unit effort from industry haul-by-haul data using generalized additive models. ICES J. Mar. Sci. 67, 1650-1658.

Marchal P., De Oliveira J.A.A., Lorance P., Baulier L., Pawlowski L., 2013, What is the added value of including fleet dynamics processes in fisheries models? Can. J. Fish. Aquat. Sci. 70, 9921010.

Mills C.M., Townsend S.E., Jennings S., Eastwood P.D., Houghton C.A., 2007, Estimating high resolution trawl fishing effort from satellite-based vessel monitoring system data. ICES J. Mar. Sci. 64, 248-255.

Muus B.J., Nielsen J.G., 1999, Sea fish. Scandinavian Fishing Year Book. Hedehusene, Denmark.

Olafsdottir A.H., Rose G.A., 2012, Influences of temperature, bathymetry and fronts on spawning migration routes of Icelandic capelin (Mallotus villosus). Fish. Oceanogr. 21, 182-198.

Overholtz W.J., Hare J.A., Keith C.M., 2011, Impacts of interannual environmental forcing and climate change on the distribution of Atlantic mackerel on the U.S. Northeast Continental Shelf. Mar. Coast. Fish. 3, 219-232.

Palmer M.C., 2008, Calculation of distance traveled by fishing vessels using GPS positional data: A theoretical evaluation of the sources of error. Fish. Res. 89, 57-64.

Reed J.K., Shepard A.N., Koenig C., Sanlon K.N., Gilmore R.G., 2005, Mapping, habitat characterization, and fish surveys of the deep-water Oculina coral reef Marine Protected Area: a review of historical and current research. In: Freiwald A., Roberts M. (Eds.), Cold-water corals and ecosystems. Berlin/Heidelberg, Springer, pp. 443-465.
Ross P.S., Barlow J., Jefferson T.A., Hickie B.E., Lee T., MacFarquhar C., Parsons E.C., Riehl K.N., Rose N.A., Slooten E., Tsai C.-Y., Wang J., Wright A.J., Yang S.C., 2011, Ten guiding principles for the delineation of priority habitat for endangered small cetaceans. Mar. Policy 35, 483-488.

Ross R.E., Howell K.L., 2013, Use of predictive habitat modelling to assess the distribution and extent of the current protection of "listed" deep-sea habitats. Divers. Distrib. 19, 433-445.

Russo T., Parisi A., Prorgi M., Boccoli F., Cignini I., Tordoni M., Cataudella S., 2011, When behaviour reveals activity: Assigning fishing effort to métiers based on VMS data using artificial neural networks. Fish. Res. 111, 53-64.

Stelzenmuller V., Rogers S.I., Mills C.M., 2008, Spatio-temporal patterns of fishing pressure on UK marine landscapes, and their implications for spatial planning and management. ICES J. Mar. Sci. 65, 1081-1091.

Trenkel V.M., Bravington M.V., Lorance P., 2012, A random effects population dynamics model based on proportions-at-age and removal data for estimating total mortality. Can. J. Fish. Aquat. Sci. 69, 1881-1893.

UN, 1982, United Nations Convention on the Law of the Sea (UNCLOS).

UN, 1992, United Nations Conference on Environment and Development (UNCED), Rio de Janeiro, Brazil.

UN, 1995, United Nations conference on straddling fish stocks and highly migratory fish stocks.

UN, 2002, World Summit on Sustainable Development (WSSD). Johannesburg, South Africa.

Walker E., Bez N., 2010, A pioneer validation of a state-space model of vessel trajectories (VMS) with observers' data. Ecol. Model. 221, 2008-2017. 